\title{
The Effect of Fencing the Forest Regeneration Stages Upon the Level of Damage Caused by Deer in the Lowland Forests of South-Western Poland
}

\author{
Bogusław Bobek, ${ }^{1 *}$ Jakub Furtek, ${ }^{2}$ Dorota Merta, ${ }^{1}$ Marta Wojciuch - Płoskonka ${ }^{2}$ \\ ${ }^{1}$ Institute of Biology, Pedagogical University, 31-054 Kraków, Podbrzezie 3, Poland; \\ b.bobek@o2.pl (B.B.); dorota.merta@up.krakow.pl (D.M.)
}

${ }^{2}$ Polish Wildlife Foundation, Żołnierska 31,30-735 Kraków, Poland; jakubfurtek@gmail.com (J.F.); martawojciuch@op.pl (M.W.P.)

*Corresponding author: e-mail: b.bobek@,02.pl; phone number: +48 603-673-503

\begin{abstract}
In the lowland forests of south-western Poland, the effect of the fencing of forest regeneration stages, aged up to 20 years, upon the level of damage inflicted by red deer (Cervus elaphus), fallow deer (Dama dama), and roe deer (Capreolus capreolus) in non-fenced patches of this age class of forest was studied. In the studied forest districts $(n=4)$, there was the highest proportion of the mixed coniferous-deciduous forest types, where the main forest-forming tree species were pine (Pinus sylvertris), birch (Betula sp.), oak (Quercus sp.), beech (Fagus sylvatica), and spruce (Picea abies). At the forest district level, the percentage of fenced areas in young forest plantations (1-10-year old) ranged, on average, from 9.1-30.9\%, and that in tickets (11-20-year old) ranged from $0.0 \%-10.2 \%$. The percentage of areas of severely damaged young plantations fluctuated between 5.7 and $14.2 \%$, and that of tickets fluctuated between $0.3-12.9 \%$. For young plantations, a statistically significant correlation (" $\mathrm{r}$ " ranged from 0.51-0.75) was obtained between percentage of area in fenced plots and the level of damage caused by deer. For thickets, this correlation was obtained solely in Pieńsk Forest District $(r=0.646)$. In the studied forest districts, the fencing of young plantations and thickets resulted in the reduction of average potential food base for cervids, from 2.9 to $10.0 \%$. An attempt was made to interpret the level of deer damage on the basis of an index, taking into account the standing crop of deciduous browse and forbs, and the population density of cervids.
\end{abstract}

Key words: cervids; damage; deer forage; fencing; forest regeneration stages; population density; Poland 


\section{Introduction}

In 2006-2016, in Poland, there has been an increase in population numbers of wild ruminants uncontrolled by game management. This pertained chiefly to the red deer, which culling increased from 40 thousand to 89 thousand [1,2]. The numbers of fallow deer, roe deer, and mouflons (Ovis musimon) also rose. The chief reason of this phenomenon was a nationwide inventory of game animals based on arbitrary guesses that markedly underestimated the respective population numbers [3]. The indirect cause was the 2000 amendment to the game law, which transferred the right to formulate the principles of game management to the Polish Hunting Association, significantly limiting the decisions of the State Forest Service in the area on population number estimates and planning the harvests of the deer populations.

The overcrowded populations of these animals caused significant damage in forest regeneration stages preventing correct forest management, the responsibility for which, under Polish law, is personally borne by foresters. For this reason, with the limited influence on the numerical regulation of deer, the Polish State Forest Service dramatically increased the financial outlays on the forest protection measures, which now amount to approx. $€ 40$ million [2]. These are principally the costs of fencing young forest plantations and thickets, i.e. a cost in which the members of the Polish Hunting Association do not participate. The fencing is extended to forest regeneration stages with high proportions of deciduous species preferred by red deer, fallow deer, and roe deer.

According to comprehensive literature overview of deer damage in European forest, there are 17 principal factors determining browsing, bark stripping, and frying impact of these large ungulates [4]. However, this overview does not include the effect of fencing the forest regeneration age classes upon the level of damage caused by cervids. The fencing of the newly established forest regeneration stages where deciduous species constitute a major proportion allowed better protection of these species against browsing and bark stripping; however, at the same time, it brought about in increased pressure from foraging by deer on the non-fenced areas of forest regeneration stages. Therefore, we hypothesized that the level of damage caused by deer in non-fenced patches of forest regeneration stages rises in line with the increased percentage of area in fenced plots of forest young plantations and thickets. The above working hypothesis was tested in the areas of four forest districts situated in south-western Poland. 


\section{Materials and Methoda}

\subsection{Study area}

The study area consisted of four forest districts situated in the lowland forests of south-western Poland (Fig. 1). The Chocianów and Ruszów Forest Districts are part of the large, compact forest complex of the Bory Dolnośląskie Forest. The area administered by the Milicz Forest District represents part of a large, compact forest complex situated in the Barycz valley. In the Pieńsk Forest District, the studies covered the fragmented forest situated in the southern part of that forest district.

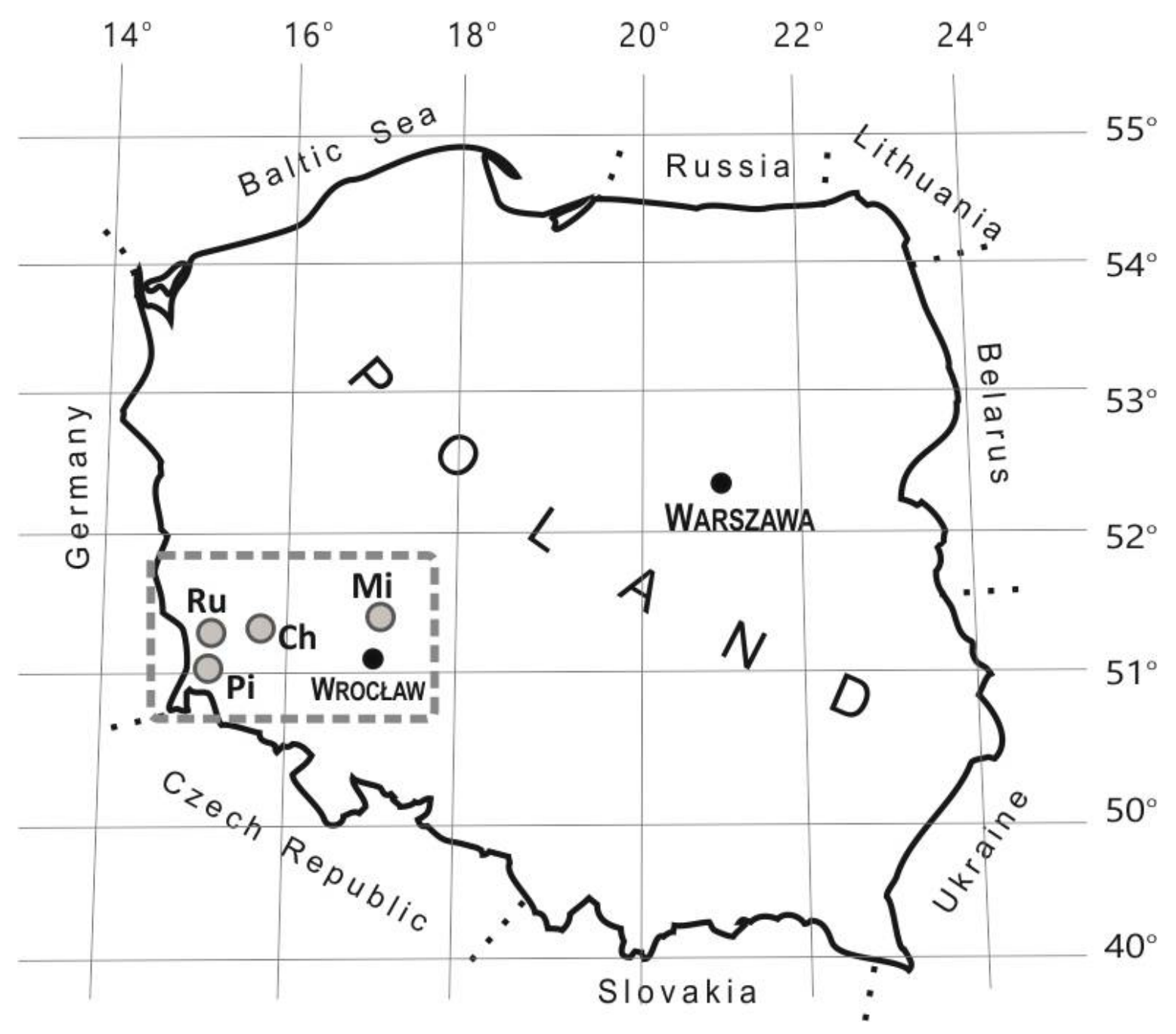


Figure 1. Location of the study area in southwestern Poland. Forest Districts: Ch - Chocianów, Mi - Milicz, Pi - Pieńsk, Ru - Ruszów.

In all forest districts included in the study, more than half of their areas were occupied by the mixed coniferous and mixed deciduous forest types (Table 1). The low proportion of deciduous forest types and a high proportion of coniferous forest types were found in the areas of the Chocianów and Ruszów Forest Districts. In turn, in the areas of the Milicz and Pieńsk Forest Districts, the proportion of coniferous forest types was very low, and that of deciduous forest types was high. Young forest plantations (aged 1-10 years) and thickets (aged 11-20 years) covered $17.2 \%-23.4 \%$ of the forested areas of the Chocianów, Milicz, and Pieńsk Forest districts, and only $9.8 \%$ of the forested areas in the Ruszów Forest District [22, 23, 24, 25] (Table $1)$.

Table 1. Characteristic of 4 forest districts representing study areas in south-western Poland $[22,23,24,25]$. Main tree species in forest districts are given in parenthesis. Pine (Pinus silvestris), spruce (Picea abies), oak (Quercus robur), beech (Fagus silvatica), birch (Betula sp.).

\begin{tabular}{|c|r|r|r|r|r|r|r|r|}
\hline & & \multicolumn{3}{|c|}{ Percent of forest types in forest area } & \multicolumn{3}{|c|}{ Percent of age class in forest } \\
districts & \\
\cline { 4 - 9 } $\begin{array}{c}\text { Name of forest } \\
\text { district and } \\
\text { dominant tree } \\
\text { species }\end{array}$ & $\begin{array}{c}\text { Forest } \\
\text { area } \\
\left(\text { ha } \times 10^{3}\right)\end{array}$ & Deciduous & $\begin{array}{c}\text { Mixed } \\
\text { deciduous } \\
\text { and mixed } \\
\text { coniferous }\end{array}$ & Coniferous & Total & $\begin{array}{c}\text { Young } \\
\text { forest } \\
\text { plantations } \\
\text { and } \\
\text { thickets }\end{array}$ & $\begin{array}{c}\text { Timber } \\
\text { stand }\end{array}$ & Total \\
\hline $\begin{array}{c}\text { Chocianów } \\
\text { (Pine, birch, } \\
\text { spruce) }\end{array}$ & 18.4 & 2.2 & 52.2 & 45.6 & 100.0 & 17.2 & 82.8 & 100.0 \\
\hline $\begin{array}{c}\text { Milicz } \\
\text { (Pine, oak, } \\
\text { beech) }\end{array}$ & 24.7 & 20.6 & 67.9 & 11.5 & 100.0 & 21.4 & 78.6 & 100.0 \\
\hline $\begin{array}{c}\text { Pieńsk } \\
\text { (Oak, beech, } \\
\text { spruce) }\end{array}$ & 8.6 & 27.3 & 72.0 & 0.7 & 100.0 & 23.4 & 76.6 & 100.0 \\
\hline $\begin{array}{c}\text { Ruszów } \\
\text { (Pine, birch, } \\
\text { spruce) }\end{array}$ & 16.5 & 1.7 & 58.2 & 40.1 & 100.0 & 9.8 & 90.2 & 100.0 \\
\hline
\end{tabular}


In the Chocianów Forest District and the Ruszów Forest District, in the recently established young plantations and thickets, Scots pine predominate to a great extend $(85 \%)$, and the remaining species are birch, common oak, and spruce. In the Milicz Forest District, the main tree species in the regeneration stages are oak, pine, and beech. Beech, oak, and spruce predominate in young forest plantations and thickets in the Pieńsk Forest District. The fencing was extended to forest regeneration plots with high proportions of deciduous species preferred by red deer, fallow deer, and roe deer.

In the study area, the levels of browsing and bark stripping of young trees situated within non-fenced young forest plantations and thickets are estimated arbitrarily in early spring by the local Forest Services. In line with the Forest Management Instruction, the damage is regarded as significant when the main shoot of a sapling is browsed or debarked in more than one-third of its circumference. If the proportion of significantly damaged saplings is lower than $20 \%$, the proportion is regarded as tolerable to the forest management, and it is not shown as such in the ISSF database. The ISSF data base indicates the level of damage in the forest sub-districts which is above $20 \%$ of significantly destroyed saplings.

\subsection{Methods}

The analysis of the impact of forest fencing upon the level of damage caused by cervids was based on the data in the Information System of the State Forests (SILP) database. In three subsequent years (2014-2016), the data pertaining to the areas of young forest plantations (aged 1 - 10 years) and the area of thickets (aged 11-20 years) was collected from the forest sub-districts $(\mathrm{n}=43)$ in four studied forest districts. The available data on the areas of fenced young plantations and thickets, and the areas for forest regeneration plots that were significantly damaged by deer were also obtained from SILP. Linear regression and Pearson correlation coefficient between the percentage of significantly damaged saplings by deer (dependent variable) and percentage of area fenced (independent variable) in each forest subdistrict were calculated. The calculations were carried out separately for young forest plantations and thickets.

Potential deer forage was calculated by using published materials on the maximum standing crop of browse and annual vegetation of forest undergrowth. The browse included the annual increments of shoots, shrubs, and dwarf shrubs available within the reach of feeding by cervids. The data was collected in the various forest types of lowland forest in Poland and 
included standing crop of deciduous browse, coniferous browse, forbs, grasses, and sedges during growing season $[5,6,7,8,9,10,11,12,13,14,15,16,17]$.

The forest types were grouped into three categories: deciduous (Tilio Carpinetum, Carici elongate-Alnetum), mixed coniferous and deciduous (Pino-Quercetum), and coniferous (Leucobro-Pinetum, Cladonio-Pinetum). In each category of habitat types of forest, the deer forage present in regeneration stages, as well as the resources in older tree stands, i.e. timber stands was estimated (Table 2).

Table 2. Average summer standing crop $\left(\mathrm{g}\right.$ dry $\mathrm{wt} / \mathrm{m}^{2}$ ) of potential food for large ungulates in 3 groups of lowland forest types representing 14 locations in Poland $[5,6,7,8,9,10,11,12,13,14,15,16,17]$. Number of forest locations in parenthesis. Amount of deciduous browse and herbs in standing crops are given in $\%$.

\begin{tabular}{|c|c|c|}
\hline Forest types and age class of stands & $\begin{array}{l}\text { Standing crop (g dry wt/ } \\
\left.\mathrm{m}^{2}\right)\end{array}$ & $\begin{array}{l}\text { Deciduous browse } \\
\text { and herbs }(\%)\end{array}$ \\
\hline \multicolumn{3}{|c|}{ Deciduous (Tilio Carpinetum, Carici elongate-Alnetum) $(\mathrm{n}=3)$} \\
\hline Young plantations and thickets & 307.6 & 61.7 \\
\hline Timber stand & 53.0 & 84.0 \\
\hline \multicolumn{3}{|c|}{ Mixed coniferous and mixed deciduous (Pino-Quercetum $)(n=7)$} \\
\hline Young plantations and thickets & 384.4 & 25.9 \\
\hline Timber stand & 55.9 & 30.9 \\
\hline \multicolumn{3}{|c|}{ Coniferous (Leucobro-Pinetum, Cladonio-Pinetum) $(\mathrm{n}=4)$} \\
\hline Young plantations and thickets & 98.5 & 18.4 \\
\hline Timber stand & 34.9 & 11.2 \\
\hline
\end{tabular}


A diet composed of deciduous browse and forbs (i.e. annual dicotyledone plants) whose nutrient values are mostly higher than that of coniferous browse, grasses, and sedges $[18,19,20,21,17]$ is essential to cervids in order for them to maintain a positive energy balance.. Therefore, it was judged that the biomass of deciduous browse and forbs will be the best for representing the effect of fencing of forest regeneration stages upon the potential fodder resources for cervids.

For each of the studied forest districts, the standing crop of deer forage was calculated on the basis of the proportion of habitat types of forest and the age classes of tree stands in the forested area of the forest districts (Table 1), as well as on the data on the biomass of deciduous browse and forbs occurring there (Table 2).

The population numbers and densities of the cervids were assessed by means of sampling plots at the end of January and the beginning February 2017 [26,27,28,29]. The levels of basal metabolism were used for the standardisation of the population densities of red deer, fallow deer, and roe deer, since these levels are good measures of energy requirements. In the calculations, the relationship between the level of basal metabolism rate (BMR) and the body mass of animals was used [30] as follows:

$\mathrm{BMR}=90 \times \mathrm{W}^{3 / 4}$,

where $\mathrm{W}$ is the body mass of a given species, and BMR is the number of $\mathrm{kcal} /$ individual $\times$ day $^{-1}$.

According to [31], the mean carcass weight of a culled red deer was $76.7 \mathrm{~kg}$, fallow deer - $31.5 \mathrm{~kg}$, and roe deer $-14.1 \mathrm{~kg}$. Substituting the carcass masses into the above equation produced the following values of basal metabolism values: red deer - $2331 \mathrm{kcal} /$ individual $\times$ $\mathrm{day}^{-1}$, fallow deer and roe deer - $1197 \mathrm{kcal}$, and $657 \mathrm{kcal}$, respectively. In view of the above, the 24 hour energy requirement of one red deer equals the energy requirement of 1.94 fallow deer, and of 3.54 of roe deer. The above conversion rates were used to find the total number of deer metabolic units (DMU) on the basis of the population densities of red deer, fallow deer, and roe deer in each forest district.

The interpretation of the level of deer damage for each forest district examined was based upon an index describing the quantity of the available of deciduous browse and forbs (BDH) in relation to population density of cervids expressed by deer metabolic units (DMU). 


\section{Results}

The percentage area of fenced patches in the regeneration stages of forest was very diversified. In young plantations, the low proportion $(9.1 \%)$ of fenced plots was noted in the Chocianów Forest District. In the remaining forest districts, the value of this variable was markedly higher, and it ranged from $18.6 \%$ within the fragmented forest in the Piensk Forest District to $30.9 \%$ in the Milicz Forest District. The mean value of this variable amounted to $22.2 \%$. The proportion of fenced areas in thickets was much lower than that in forest plantations. In the Chocianów Forest Districts, the thickets were not fenced at all. In the remaining forest districts, the proportions of fenced areas in thickets ranged from $0.5 \%$ in the Milicz Forest District to $10.2 \%$ in the Piensk Forest District. Table 3 shows the percentage share of fenced areas located in the four forest districts calculated jointly for young plantations and thickets.

The percentage shares of damaged areas were also very diversified. In young plantations, the mean value amounted to $8.4 \%$, and it ranged from $5.7 \%$ to $14.2 \%$ in Pieńsk FD and Ruszów FD, respectively. In thickets, the average percentage of area damaged by deer was calculated as $8.1 \%$. It varied from $0.3 \%$ (Pieńsk FD) to $12.9 \%$ (Chocianów FD). The percentage share of the damaged areas calculated jointly for young plantations and thickets is presented in Table 3.

Table 3. Characteristics of young plantations and thickets in the forest of southwestern Poland. The data of total area, fenced area and damaged area are presented in hectares and accumulated for three years (2014-2016). Percent of fenced area and percent of damaged area by deer is also given.

\begin{tabular}{|c|r|r|r|r|r|r|}
\hline Name of Forest District & $\begin{array}{c}\text { Total area } \\
\text { (A) }\end{array}$ & $\begin{array}{c}\text { Fenced area } \\
\text { (B) }\end{array}$ & (B/A)*100 & $\begin{array}{c}\text { Unfenced } \\
\text { area } \\
\text { (C) }\end{array}$ & $\begin{array}{c}\text { Damaged } \\
\text { area } \\
\text { (D) }\end{array}$ & (D/C)*100 \\
\hline CHOCIANÓW & 9484.1 & 476.0 & $5.0 \%$ & 9008.1 & 903.1 & $10.0 \%$ \\
\hline
\end{tabular}




\begin{tabular}{|l|r|r|r|r|r|r|}
\hline MILICZ & 15928.9 & 2739.9 & $17.2 \%$ & 13188.8 & 1111.4 & $8.4 \% \mathrm{~s}$ \\
\hline PIEŃSK & 6079.9 & 780.8 & $12.8 \%$ & 5299.2 & 102.9 & $1.9 \%$ \\
\hline RUSZÓW & 4878.1 & 764.5 & $15.7 \%$ & 4113.5 & 446.1 & $10.8 \%$ \\
\hline TOTAL/MEAN* & $\mathbf{3 6 ~ 3 7 1 . 0}$ & $\mathbf{4 7 6 1 . 2}$ & $\mathbf{1 3 . 1 \%}$ & $\mathbf{3 1 ~ 6 0 9 . 7}$ & $\mathbf{2 5 6 3 . 5}$ & $\mathbf{8 . 1 \%}$ \\
\hline
\end{tabular}

*Weighted mean

In young plantations, the average damaged area of forest subdistrict ranged from $6.92 \% \pm$ $1.45(\bar{x} \pm \mathrm{SE})$ in Pieńsk FD to $9.58 \% \pm 2.35$ in Ruszów FD. The maximum percentage of damaged area in this age class of stands, which was calculated separately for the forest subdistrict, was from $15.5 \%$ in Chocianów FD (Fig. 2) to $81.7 \%$ in Milicz FD. The average level of deer damage in the forest subdistricts was much lower in thickets than in young plantations. The percentage share of the damaged area in thickets of forest subdistricts varied from $0.57 \% \pm$ 0.25 to $7.66 \% \pm 1.59$ in Pieńsk FD and Ruszów FD, respectively. The highest percentage of damaged area by deer estimated separately for thickets in the forest subdistricts fluctuated from $3.8 \%$ in Pieńsk FD to $30.4 \%$ in Ruszów FD.

Within all studied forest districts, the increased proportion of the fenced areas in young plantations resulted in the increase in the area of plots damaged by wild ungulates in non-fenced plots of the same age class (Table 4, Fig. 2). The obtained Pearson correlation coefficients were high, statistically significant, and ranged from 0.508 to 0.749 . The fencing measure explained from $25.8 \%$ to $56.1 \%$ of the damage caused by wild ungulates in forest plantations. The fencing in thickets significantly affected the levels of damage in the fragmented forest in the Piensk Forest District. In the remaining forest districts, no significant effect of fencing upon the level of damage caused by wild ungulates in thickets has been found.

Table 4. Linear regression parameters and correlation coefficients between the proportion of the fenced plots in young forest plantations (x) and thickets, and the level of damage caused by deer 
in the studied age classes (y). NS - non-significant. Sample size represents the number of forest sub-district used in the calculations.

\begin{tabular}{|c|c|c|c|c|c|c|}
\hline $\begin{array}{l}\text { Name of Forest district } \\
\text { and age classes of forest } \\
\text { stand }\end{array}$ & Simple size & $\begin{array}{l}\text { Intercept } \\
\text { "a" }\end{array}$ & Slope "b" & $\begin{array}{l}\text { Coefficient } \\
\text { of } \\
\text { correlation } \\
\text { "r" }\end{array}$ & $r^{2}$ & p-values \\
\hline \multicolumn{7}{|l|}{ CHOCIANÓW } \\
\hline $\begin{array}{l}\text { Young } \\
\text { plantations }\end{array}$ & 27 & 2.722 & 0.479 & 0.626 & 39.1 & 0.001 \\
\hline Thickets & - & - & - & - & - & - \\
\hline \multicolumn{7}{|l|}{ MILICZ } \\
\hline $\begin{array}{l}\text { Young } \\
\text { plantations }\end{array}$ & 54 & -7.781 & 0.492 & 0.508 & 25.8 & 0.001 \\
\hline Thickets & 54 & 2.705 & 1.253 & 0.306 & - & NS \\
\hline \multicolumn{7}{|l|}{ PIEŃSK } \\
\hline $\begin{array}{l}\text { Young } \\
\text { plantations }\end{array}$ & 21 & 1.726 & 0.243 & 0.563 & 31.7 & 0.008 \\
\hline Thickets & 24 & -0.186 & 0.047 & 0.646 & 41.7 & 0.001 \\
\hline \multicolumn{7}{|l|}{ RUSZÓW } \\
\hline $\begin{array}{l}\text { Young } \\
\text { plantations }\end{array}$ & 27 & -14.960 & 0.502 & 0.749 & 56.1 & 0.001 \\
\hline Thickets & 27 & 13.417 & -0.058 & -0.248 & - & NS \\
\hline
\end{tabular}

Figure 2. The relationship between the fenced areas of young forest plantations (age up to 10 years old) (X) and level of damage caused by cervids on non-fenced part in that age class (Y). Data based upon sub forest district in Chocianów Forest District and were collected during 3 year period $(2013-2015)$. 


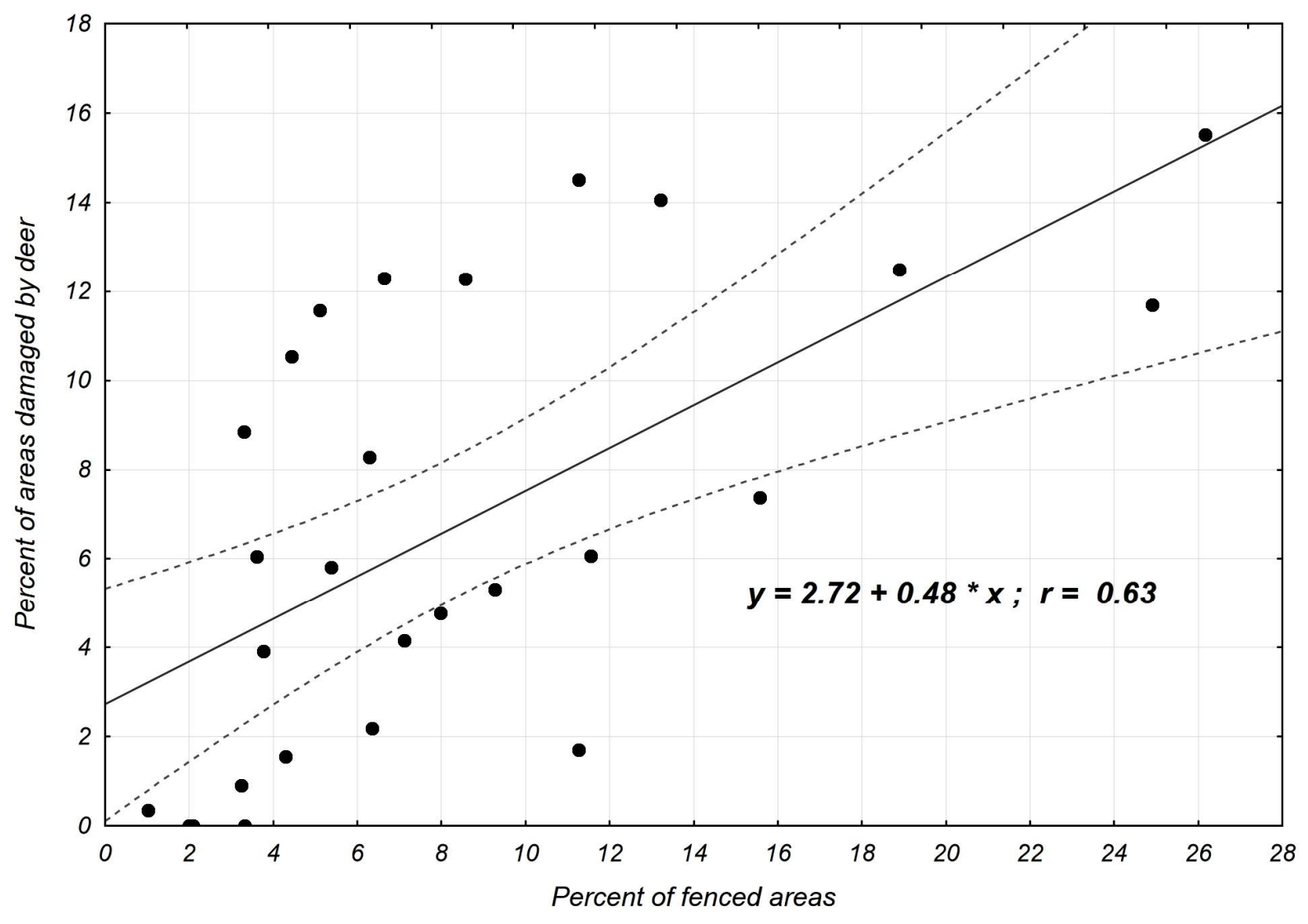

The results of linear regression show that the rate of increase in the damage in plantations compared to the proportion of fenced plots was the lowest in the fragmented forest of Pieńsk FD $(b=0.243)$. In the remaining forest districts, the " $b$ " index representing the angle of the inclination of the linear regression line to the $\mathrm{x}$-axis was much greater and stayed within the range from 0.479 to 0.502 (Table 4 ).

\section{Discussion}

The level of damage caused by cervids is often analysed on the basis of the population density, as well as the quantity and quality of potential deer forage. The results of these analyses are not unambiguous. For example, it is reported that the increase in the biomass of deer food resources can either increase $[32,33,34]$ or decrease $[35,36,37]$ the level of deer damage in forest regeneration stages. The prevalent number of publications provides the examples of the adverse 
impact of the cervid population density on the extent of deer damage in forest regeneration stages $[38,39,40,41,42]$; however, only a few studies do not show such effect $[43,44]$. The above controversies may stem from the imprecise measurements of the biomass of deer forage, the inaccurate estimate of population numbers, as well as by the lack of standardisation in population densities of various species of Cervidae jointly inhabiting the study areas.

The studies on the food habits in Cervidae showed that the composition of their natural diet is principally formed of browse, i.e. the annual increments of shoots and twigs in trees shrubs and dwarf shrubs accessible during feeding by these animals, as well as the vegetation of forest undergrowth $[45,46,47]$. The additional elements of the diet could include bark [40], and - in mast years - acorns and beech nuts [48]. However, the energy budget in these animals is primarily based on feeding on browse and the plants of forest undergrowth. Therefore, in the studies of the level of deer damage, it is necessary to have well-documented results pertaining to the quantity and species composition of these two components of deer forage in the whole forest habitat.

Many publications (see below) report that, in lowland forests of Poland, the highest biomass of browse and ground flora in summer occurs in mixed coniferous and mixed deciduous forests, slightly lower in deciduous forests, and the lowest in coniferous forests (Table 2). In summer, the deciduous forest regeneration stages, i.e. young plantations and thickets offer almost six times (5.8 times) more forage to cervids than timber stands. Slightly greater differences (6.9 times) were noted in mixed coniferous-deciduous forest. In coniferous forest, however, the differences in the biomass of deer forage between regeneration stages and timber stands were the lowest, i.e. 2.8 times. The species composition of deer forage differed markedly between the studied habitat types of forest. The proportion of deciduous browse and forbs (annual dicotyledone plants) was highest in deciduous forest, where it amounted to an average of $72.8 \%$. In mixed coniferous forest, mixed deciduous forest, and in coniferous forest, the value amounted to $28.4 \%$ and $14.6 \%$, respectively (Table 2) [5,6,7,8,9,10,11,12,13,14,15,16,17].

The results of analyses pertaining to the effects of the fencing of regeneration stages upon the decreases in the deer forage composed of deciduous browse and forbs are compiled in Table 5. Although the proportion of the area of young forest plantations and thickets in the forested area of the studied forest districts ranged from $9.8 \%$ to $23.4 \%$ (Table 1 ), in the case of the lack of 
fencing of this age class in the studied forest districts, the regeneration stages would provide, on average $52.3 \%$, of the total biomass of deer forage made of deciduous browse and forbs in summer (Table 5). Within the study area, the differentiated proportion of fenced young plantation and thickets $(5.0-17.2 \%)$ reduced the standing crop deer forage in the range from $2.9 \%$ to $10.0 \%$ in summer. These results enabled the calculation that the limiting $1 \%$ of the surface area of regeneration stages reduced the availability of the biomass of deer forage in the whole forest environment by an average of $0.51 \%$.

Table 5. The effect of fencing young forest plantations and thickets (forest regeneration stages up to 20 years old) on the potential standing crop of deciduous browse and herbs ( $\mathrm{g}$ dry $\mathrm{wt} / \mathrm{m}^{2}$ ) during summer in four forest districts situated in south-western Poland. The percentages of the fenced areas of forest regeneration stages $(F)$ in these forest districts are given. The calculations used the material contained in Tables 2 and 3.

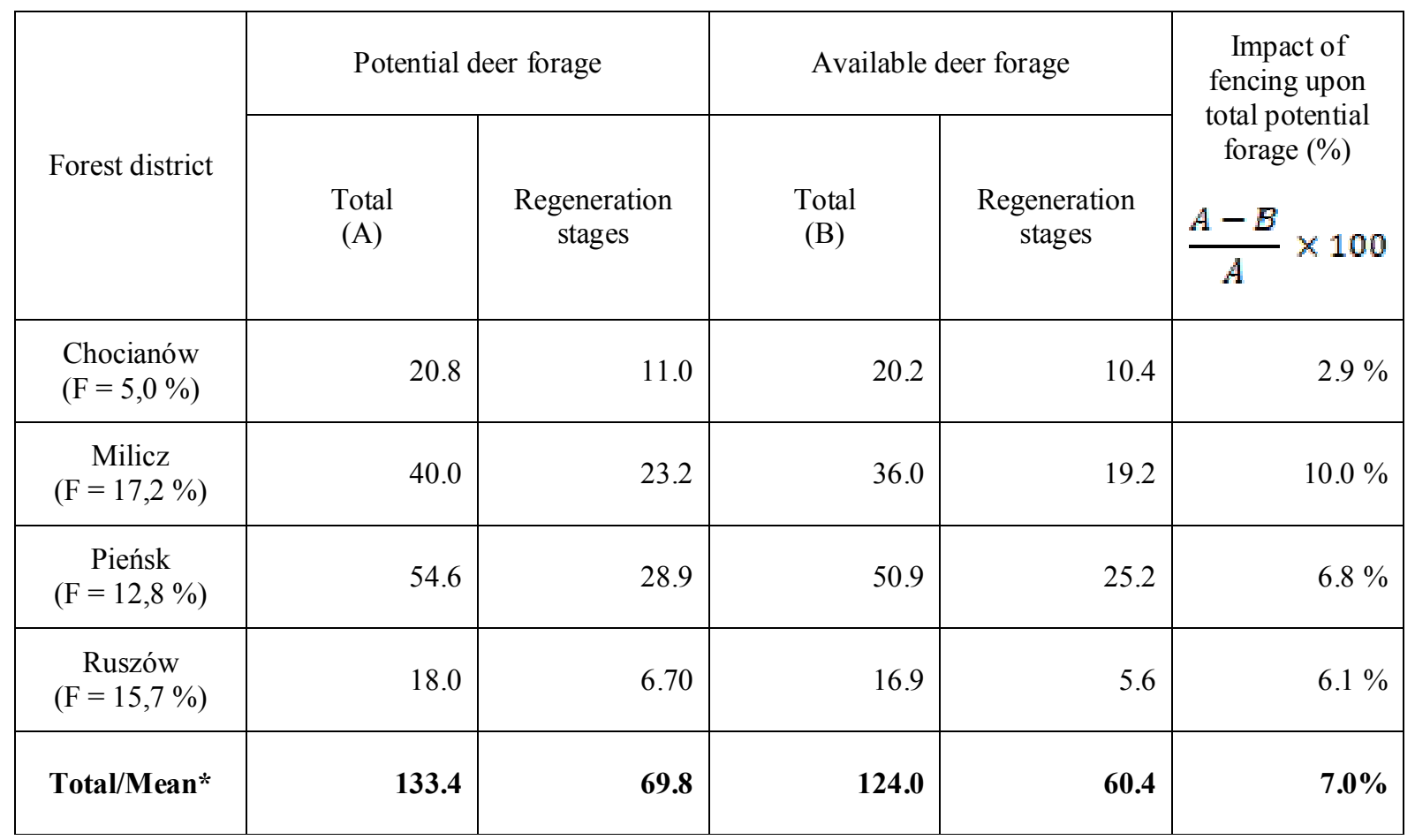

*Weighed mean 
The second factor that can affect the level of deer damage in forest regeneration stages is the population density of Cervidae. In the study area, the population densities of these animals are much diverse and, when calculated per 1000 hectares of forest, they range from 10.1 to 63.0 for red deer, and from 25.8 to 200.0 for roe deer. Additionally, in the Milicz Forest District, there is a population of fallow deer whose density was estimated to be 20.0 individuals/1000 hectares of forest (Table 6). The densities of the three cervid species were standardised by introducing deer metabolic units (cf. Methods) allowing the comparison of the pressures from feeding by these animals in four forest districts under study. The obtained results indicate that the density of deer metabolic units was greatly diversified. When calculated per 1000 hectares of forest, it ranged from 48.3 units in the Chocianów Forest District to 110.1 units in the Milicz Forest District (Table 6).

Table 6. Population densities of cervids (N/1000 hectares of forest) within the studied forest districts in south-western Poland estimated at the beginning of January and February 2017 $[26,27,28,29]$. Also given is the density of deer metabolic units (DMU/1000 hectares of forest).

\begin{tabular}{|c|r|r|r|r|r|r|r|}
\hline \multirow{2}{*}{$\begin{array}{c}\text { Forest } \\
\text { district }\end{array}$} & \multicolumn{2}{|c|}{ Red deer } & \multicolumn{2}{c|}{ Fallow deer } & \multicolumn{2}{c|}{ Roe deer } & \multicolumn{2}{c|}{$\begin{array}{c}\text { Deer Metabolic Unit } \\
\text { Total }\end{array}$} \\
\cline { 2 - 8 } & $\begin{array}{c}\text { Population } \\
\text { Density }\end{array}$ & $\begin{array}{c}\text { Deer } \\
\text { Metabolic } \\
\text { Unit }\end{array}$ & $\begin{array}{c}\text { Population } \\
\text { Density }\end{array}$ & $\begin{array}{c}\text { Deer } \\
\text { Metabolic } \\
\text { Unit }\end{array}$ & $\begin{array}{c}\text { Population } \\
\text { Density }\end{array}$ & $\begin{array}{c}\text { Deer } \\
\text { Metabolic } \\
\text { Unit }\end{array}$ & \\
\hline Chocianów & 29.5 & 29.5 & - & - & 66.7 & 18.8 & \\
\hline Milicz & 62.3 & 62.3 & 20.0 & 10.3 & 133.1 & 37.6 & \\
\hline Pieńsk & 10.1 & 10.1 & - & - & 200.0 & 56.3 & \\
\hline Ruszów & 63.0 & 63.0 & - & - & 25.8 & 7.3 & \\
\hline
\end{tabular}

The previous review of publications dealing with the issues of deer damage in the forest environment did not yield an unambiguous conclusion of the separate effects of the quantity of deer forage and population density of cervids upon the level of damage in forest regeneration 
areas. Therefore, it was deemed that, without an index taking into account the relation between the biomass of the available biomass of deer forage (BDH) and the density of population (DMU), it would be impossible to explicitly interpret the results obtained in the presented study. For each of forest districts examined, the derived index (BDH/DMU) gives the quantity of the available of deciduous browse and forbs per one deer metabolic unit.

The value of this index explains well the diversity in the level of deer damage in the study area. The lowest value of the index (239) is characteristic for Ruszów FD, where the percentage of area in regeneration stages damaged by deer is highest (10.8\%, see Table 2). Higher values of the index in Chocianów FD and in Milicz FD resulted in a lower percentage of areas damaged by cervids in regeneration stages (Fig 3). In Pieńsk FD, where the level of the area of damaged young forest plantation and thickets amounts to a mere $2 \%$, the index is high and reaches the value of 674 .

Figure 3. The relationship between the levels of deer damage in forest regeneration stages caused by cervids and the summer biomass of deciduous browse and herbs (BDH) available to these animals calculated per one deer metabolic unit (DMU). The graph was drawn on the recalculated BDH data from Table 5 expressed in kg dry wt / 1000 ha of forest and deer metabolic units (Table 6). The data represent four forest districts (Chocianów, Milicz, Pieńsk, and Ruszów) situated in south-western Poland. 


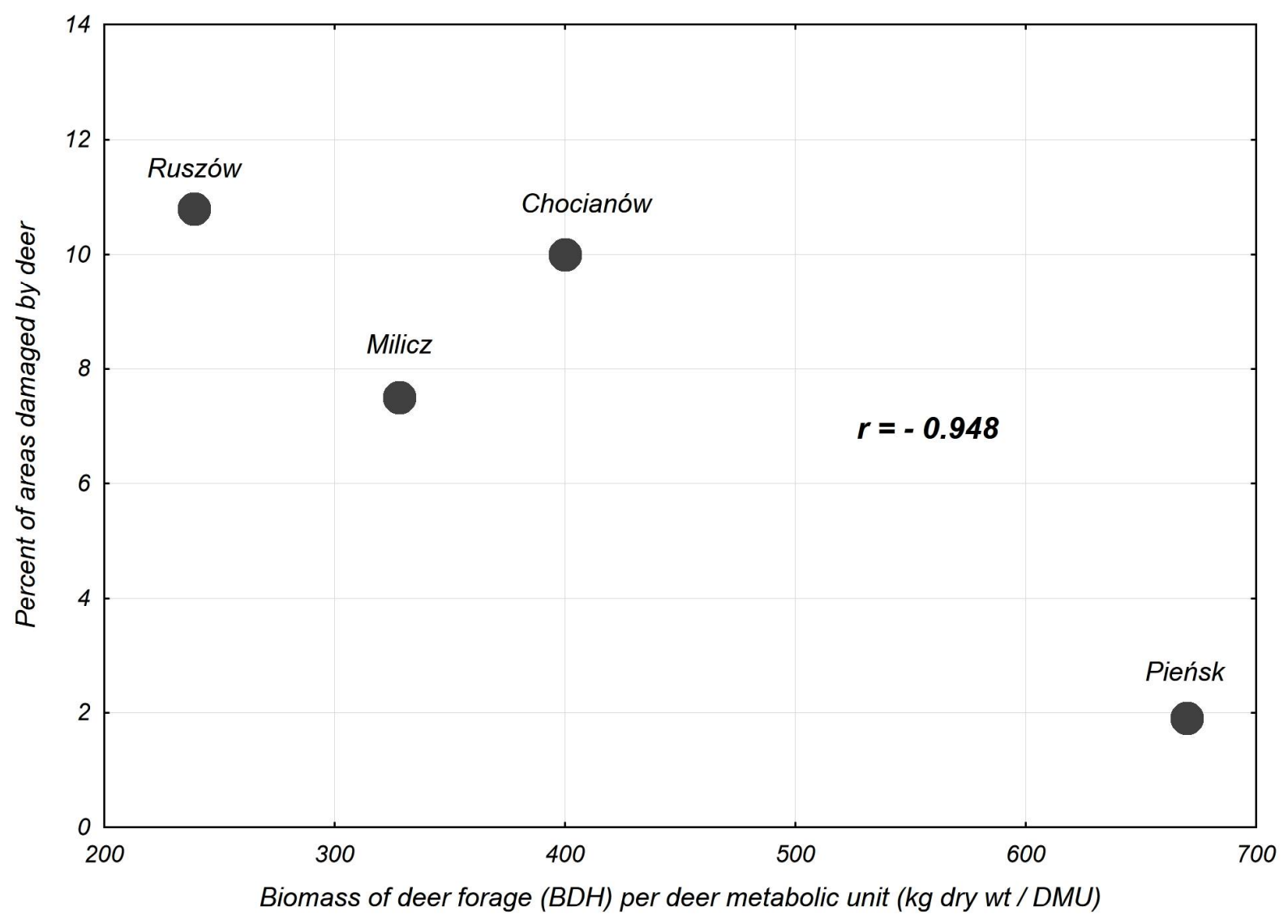

\section{Conclusions}

The relationship between the value of the BDH/DMU index and the level of deer damage was determined only in four forest districts. For this reason, and because of a low number of samples, the correlation coefficients obtained (although high at $r=-0.948$ ) should be treated as tendencies to mark the directions of research aimed at learning about the mechanisms by which the deer damage develop in the forest regeneration stages. In case where this relationship will be positively verified by a higher number of samples, knowing the value of the BDH/DMU index will be enough to forecast and limit the level of deer damage in forest regeneration stages as well as to decrease the area of fenced plots in this age class of the forest stand. To sum up, in the presented paper, it has been shown that the fencing of forest regeneration stages can remarkably limit the potential base of deer forage. The level of deer damage depends on both the quantity of available deer forage on unfenced forest regeneration stages and in the remaining age classes of 
forest stands, as well as on the population density of cervids expressed in the form of deer metabolic units. The lowered level of fencing in forest regeneration stages will limit the damage in this age class and bring about significant financial benefits; however, such a programme must be preceded by a remarkable reduction of the population of cervids.

Acknowledgments: This work was financially supported by Chocianów, Milicz, Pieńsk and Ruszów Forest Districts. We would like to thank local State Forest Service for help in providing the database of deer damage and the level of fencing in forest representation stages.

Author Contributions: All authors obtained funding, designed research methods and wrote and partly edited the manuscript. Bogusław Bobek and Marta Wojciuch-Płoskonka collected and analysed data.

Conflict of Interest: the authors declare no conflict of interest

\section{References}

1. Budna, E.; Grzybowska, L.; Karczewicz, A. Forestry 2006 - Information and Statistical Papers. Central Statistical Office, Warsaw 2006, pp 1-312.

2. Pac, T.; Raczkowska, J.; Wilamowska, L. Forestry 2016 - Information and Statistical Papers. Central Statistical Office, Warsaw 2016, pp 1-365.

3. Bobek, B.; Merta, D.; Furtek, J.; Wojciuch-Płoskonka, M.; Kopec, K.; Maślanka, J.; Ziobrowski, M. Population dynamics of wild ungulates in various regions of Poland estimated by different methods. Stud. i Mat. CEPL w Rogowie 2013, 36, 3, 88-101 (in Polish with English sum.).

4. Gerhardt, P.; Arnold, J.M.; Hacklander, K.; Hochbichler, E. Determinants of deer impact in European forests - a systematic literature analysis. For. Ecol. Manage. 2013, 310, 173-186. 
5. Dzięciołowski, R. The quality, quantity and seasonal variation of food resources available to red deer in various environmental conditions of forest management. Warsaw 1969, pp 1-295.

6. Aulak, W. Studies on herb layer production in the Ciracaeo-Alnetum Oberd. 1952 Association. Ekol. Pol. A. 1970, 19/19, 411-427.

7. Dzięciołowski, R. Net primary production of herbaceous plants in four forest association. Folia For. Pol. A. 1970, 16, 91-108 (In Polish with English summary).

8. Moszyńska, B. Estimation of the green top production of the herb layer in a bog pinewood, Vaccinio uliginosi Pinetum. Ekol. Pol. A. 1970, 18, 779-803.

9. Plewczyńska, U. Herb lager production and plant fall in the association Pino- Quercetum Kozlowska 1925 in Pisz Forest. Ecol. Pol. A. 1970, 36, 757-778.

10. Wójcik, Z. Primary production of the herb layer and plant fall in a dry pine forest (Cladonio-Pinetum) Kobendza 1930 in the Kampinos National Park. Ekol. Pol. A. 1970, 18, 393 409.

11. Banasik, J. Ground flora production in a stand of Tilio-Carpinetum. Bull. Pol. Acad. Sci. Cl. 1973, II 21, 593-599.

12 Bobek, B.; Borowski, S.; Dzięciołowski, R. Browse supply in various forest ecosystems. Pol. Ecol. Stud. 1975, 1, 17-32.

13. Bobek, B.; Perzanowski, K.; Siwanowicz, J.; Zielińska, J. Deer pressure on forage in a deciduous forest. Oikos 1979, 32, 373-380.

14. Bobek, B.; Perzanowski, K.; Kossak, S.; Merta, D. The system of managing wildlife and forest in central Europe. The For. Chron. 1994, 70, 5, 550-554.

15. Tomek, A.; Jamrozy, G.; Kubacki, T.; Tomek, Z. Standing crop and consumption of herb layer plant in fresh coniferous forest. Ekol. Pol. 1976, 24, 377-389. 
16. Borowski, S.; Dzięciołowski, R.; Browse supply in lowland forest of eastern Poland. Holarctic Ecol. 1980, 3, 203-213.

16. Perzanowski, K.; Pradel, A.; Sikorski, D.; Mydlarz, J. Food resources for deer in Niepołomicka Forest. Acta Theriol. 1982, 27, 36, 509-519.

17. Siuta, A. Assessment of the potential feed base for red deer (Cervus elaphus L.)in the Romnicka Forest. Zesz. Nauk. AR. 2006, 313, 7-129 (In Polish with English Summ.).

18. Drożdż, A.; Osiecki, A.; Intake and digestibility of natural feeds by roe deer. Acta theriol. 1973, 18, 3, 81-91.

19. Perzanowski, K. The effect of winter food composition on roe deer energy budget, Acta Theriol. 1978, 23, 3, 451-467.

20. Mould, E.D.; Robbins, C.T. Digestive capabilities in elk compared to white- tailed deer. J. Wildl. Manage. 1982, 46, 22-29.

21. Gonzalez- Hernandez, M.P.; Silva-Pando, F.J. Nutritional attributes of understory plants known as components of deer diet. J. Range. Manage. 1999, 52, 132-138.

22. Forest management plan for Forest District Pieńsk in 2006-2015. Pieńsk 2006, in Polish (unpubl. data).

23. Forest management plan for Forest District Chocianów 2014-2023. Chocianów 2014, in Polish (unpubl. data).

24. Forest management plan for Forest District Ruszów 2015-2024. Ruszów 2015, in Polish (unpubl. data).

25. Forest management plan for Forest District Milicz 2016-2025. Milicz 2016, in Polish (unpubl. data). 
26. Bobek, B. Game management plans for management unit of „Barycz Valley” for 20172027 period. Regional Directorate of State Forest in Wrocław, Wrocław 2017a, pp. 1-44 (In Polish)

27. Anon. Game management plans for management unit of „Bory Dolnośląskie PołudniowoZachodnie" for 2017-2027 period. Regional Directorate of State Forest in Wrocław, Wrocław 2017b, pp. 1-44 (In Polish)

28. Anon. Game management plans for management unit of „Bory Dolnośląskie PółnocnoWschodnie" for 2017-2027 period. Regional Directorate of State Forest in Wrocław, Wrocław 2017c, pp. 1-44 (In Polish)

29. Anon. Game management plans for management unit of „Przedgórze Sudeckie” for 20172027 period. Regional Directorate of State Forest in Wrocław, Wrocław 2017d, pp. 1-65 (In Polish)

30. Drożdż, A.; Weiner, J.; Gębczyńska, Z.; Krasińska, M. Some bioenergetic parameters of wild ruminants. Pol. Ecol. Stud. 1975. 1,2, 85-101.

31. Sierpinski, C.; Mrugała, Z.; Bazan, S.; Korpas, B. Characteristic of Game Management Unit „Dolina Baryczy”. In Management and conservation of wildlife populations in Regional Directorate of State Forest in Wrocław. Bobek, B.; Płaksej, A.; Frąckowiak, W.; Merta, D. (eds). Vol. 2. RDLP-Wrocław, Poland, 2007, pp 1-280.

32. Pepin, D.; Renaud, P.C.; Boscardin, Y.; Goulard, M.; Mallet, C.; Anglard, F.; Ballon, P. Relative impact of browsing by red deer on mixed coniferous and broad-leaved seedlings - an enclosure-based experiment. For. Ecol. Manage. 2006, 222, 302-313.

33. Bobrowski, M.; Gillich, B.; Stolter, C. Modelling browsing of deer on beech and birch in northern Germany. For. Ecol. Manage. 2015, 358, 212-221.

34. Nevalainen, S.; Matala, J.; Korhonen, K.T. Ihalainen, A.; Nikula, A. Moose damage in National Forest Inventories (1986-2008) in Finland. Silva Fennica 2016, 50, 2, 1410-1423. 
35. Nopp-Mayr, U.; Reimoser, F.; Volk, F. Predisposition assessment of mountainous forests to bark peeling by red deer (Cervus elaphus L.) as a strategy in preventive forest habitat management. Wildl. Biol. Pract. 2011, 7, 1, 66-89.

36. Harmer, R.; Kiewitt, A.; Morgan, G.; Gill, R. Does the development of bramble (Rubus fructicosus L.) facilitate the growth and establishment of tree seedlings in the woodlands by reducing deer browsing damage? Forestry 2010, 83, 1, 93-102.

37. Jaremo, A.; Minderman, J.; Bunnefield, N.; Zidan, J.; Mansson, J. Managing landscape for multiple objectives: alternative forage can reduce the conflict between deer and forestry. Ecosphere 2014, 5, 8, 1-14.

38. Ward, A.I.; White, P.C.L.; Walker, N.J.; Critchley, C.H. Conifer leader browsing by roe deer in English upland forests: effects of deer density and understorey vegetation. For. Ecol. Manage. 2008, 256, 1333-1338.

39. Koda, R.; Fujita, N. Is deer herbivory directly proportional to deer population density? Comparison of deer feeding frequencies among six forests with different deer density. For. Ecol. Manage. 2011, 262, 432-439.

40. Verheyden, H.; Ballon, P.; Bernard, V.; Saint-Andrieux, C. Variations in bark-stripping by red deer Cervus elaphus across Europe. Mammal Rev. 2006, 36, 217-234.

41. Kamler, J.; Homolka, M.; Barančeková, M.; Krojerová-Prokešová, J. Reduction of herbivore density as a tool for reduction of herbivore browsing on palatable tree species. Eur. Jour. For. Res. 2010, 129, 155-162.

42. Klopcic, M.; Jerina, K.; Bocina, A. Long-term changes of structure and tree species composition in Dinaric uneven-aged forest: are red deer important factor? Eu. Jour. For. Res. 2010, 129, 3, 277-288. 
43. Bergquist, J.; Orlander, G. Browsing damage by roe deer on Norway spruce seedlings planted on clearcuts of different ages: 1. Effect of slash removal, vegetation development, and roe deer density. For. Ecol. Manage. 1998, 105, 283-293.

44. Heinze, E; Boch, S.; Fischer, M.; Hessenmöller, D.; Bernd, K.; Müller, J.; Prati, D.; Schulze, E.D.; Seele, C.; Socher, S.; Halle, S. Habitat use of large ungulates in north-eastern Germany in relation to forest management. For. Ecol. Manage. 2011, 261, 288-296.

45. Gebert, C.; Verheyden-Tixier, H. Variations of diet composition of Red Deer (Cervus elaphus L.) in Europe. Mammal Rev. 2001, 31, 3, 189-201.

46. Cornelis, J.; Casaer, J.; Henry, M. Impact of season, habitat and research techniques on diet composition of roe deer (Capreolus capreolus): a review. J. Zool. London. 1999, 248, 195207.

47. Obidziński, A.; Kiełtyk, P.; Borkowski, J.; Bolibok, L.; Remuszko, K. Autumn - winter diet overlap of fallow, red and roe deer in forest ecosystems, Southern Poland. Cent. Eur. J. Biol. 2013, 8,1, 8-17.

48. Picard, J.F.; Oleffe, P.; Boisaubert, B. Influence of oak mast on feeding behaviour of Red Deer (Cervus elaphus L.). Annales des Sciences Forestieres 1991, 48, 547-599. 